\title{
Translation and Response between Maurice Blanchot and Lydia Davis
}

\author{
Jonathan Evans \\ University of Portsmouth
}

The American writer and translator Lydia Davis's first book as an author, The Thirteenth Woman and Other Stories, was published in 1976, a year after she published her first book length translation, Arabs and Israelis: A dialogue, by Saul Friedländer and Mahmoud Hussein, which Davis co-translated with her then husband Paul Auster. In her career, writing has always co-existed with translating. Her identity as a writer is sometimes overshadowed by her activity as a translator: as James Wood remarks, when he first heard of Davis in the mid-1990s, "[s] he was known as a translator of the French autobiographer Michel Leiris and the philosopher and critic Maurice Blanchot" (88). Since the 1990s, she has published two other major translations: The Way by Swann's, a translation of Marcel Proust's Du côté de chez. Swann, in 2002 and a translation of Flaubert's Madame Bovary in 2010, showing a continuation of her translation activity throughout her career.

Her most enduring relationship as a translator is, however, with Maurice Blanchot. She began publishing her translations of his work in 1975, when an early draft of her translation of Death Sentence appeared in the magazine Living Hand, which Davis and Auster edited. Over the next eighteen years, Davis translated six books of Blanchot's: L'Arrêt de mort (1948) as Death Sentence (1978), Au temps voulu (1951) as When the Time Comes (1985), Celui qui m'accompagnait pas (1953) as The One Who Was Standing Apart from Me (1993), Le dernier homme (1957) as The Last Man (1987), La Folie du jour (1973) as "The Madness of the Day" (1977) and The Gaze of Orpheus and other essays (1981). The first four of these are novella length texts, called "récits" by Blanchot. The fifth, "The Madness of the Day", is a short text that was published separately as a book in 1981, despite only being nine full pages in length in its 1977 English magazine publication and the same when it was reprinted in The Station Hill Blanchot Reader (191-99). The sixth book was the first volume of Blanchot's essays published in English, which came out just before two other translations of Blanchot's literary criticism, The Sirens' Song, edited by the writer Gabriel Josipovici and published by Harvester Press in England, and Ann Smock's translation of The Space of Literature for the University of Nebraska Press.

Davis has stated how important translating Blanchot was for her as a translator. While translating him she "learned to stay extremely close to the text ... practising an extreme fidelity" (Proust 7). She reports that she corresponded with Blanchot, who stressed her autonomy as the translator (Ziolkowski), which was no doubt an important confidence boost for her as a less established translator. Her care and interest in Blanchot can be seen in the fact that she published early versions of the translations in magazines (Blanchot, "Death-Halt"; "Death Sentence"; "Madness") which, with the exception of Michel Leiris's work (see acknowledgements page of her translation of Leiris's Brisées), is something she has not done with her other translations, although it mirrors her practice with her own short stories.

While Blanchot's importance to Davis as a translator seems clear, it is harder to establish how 
important he is for her as a writer, i.e. how her activity translating Blanchot has impacted on her writing and how her identities as author and translator are affected by this. Davis has mentioned that she shares some sort of affinity with Blanchot as a writer which drew her to translating him (McCaffery 67-68) and the prevalence of the Blanchot translations in Davis's bibliography has influenced many of the critics who have written about Davis. They tend to approach Davis through the lens of Blanchot's critical writings, suggesting that his ideas have influenced Davis. Beverly Haviland noted "Davis's excellent work as a translator of Maurice Blanchôt [sic] seems to have made her as distrustful of language as he is" (153), an impression that Marjorie Perloff deepens with reference to Blanchot's observation that "ordinary language" is also full of misunderstanding (205). Likewise, Josh Cohen posits Blanchot's influence when, in an article on irony which is heavily grounded in Blanchot's thinking, he chooses Lydia Davis's work as a way of demonstrating how the "mode of (non)revelation work[s] within the specific space of individual literary texts" ("Aesthetic Theory" 76), noting that his choice of Blanchot's American translator is not coincidental. Cohen also foregrounds elsewhere ("Reflexive incomprehension" 502) how Blanchot's critical writings can be used to understand Davis's work.

Blanchot has become best known in the English speaking world for his literary criticism (see, for example, introductions to his work by Gill or Haase and Large), but Davis translated more of his récits, and while there is certainly some connection with Blanchot's theories of literature in Davis's work, I propose that it is possible to read elements of Davis's work as a response to Blanchot's fiction. I refer specifically to Davis's story "Story" (Story 27-30; reprinted in Break it down 3-7), and Blanchot's récit La Folie du jour/ "The Madness of the Day", which are the focus of this article. La Folie du jour was one of the first texts Davis translated on her own, showing an early interest in Blanchot, and especially in his narrative manipulations. Davis published an early translation in Tri-Quarterly in 1977. A revised translation was published in 1981 as a small book by Station Hill Press. This revised translation was reprinted in The Station Hill Blanchot Reader (191-99). Davis's translation can be considered as one aspect of her response to the text and her revision suggests a continuing involvement with it. Both versions tend to follow the source text closely, replicating the sentence and paragraph structures of the French. The revised version is very similar to the first translation, with most of the changes being minor stylistic alterations which restore ambiguities present in the French that were smoothed over in the first translation. For example, "ce jour" (Folie 10) is first translated, quite plausibly, as "this daylight" ("Madness" 168) and then revised to "this day" (Station Hill 191). Translating in a way that causes the target text to follow the source writer's style more closely can be read as showing a respect for that style and trust in its ability to achieve its goals. Davis's translation can be characterised as a form of what Susan Bernofsky has called "service translation" (ix), where the translator does not try to imprint their own authorial style onto a translation - something that Bernofksy sees in translations by Goethe, Hölderlin and Kleist.

"Story" could be considered as Davis's more authorial reaction to Blanchot's récit. The history of La Folie du jour suggests one reason to compare it with "Story": it was first published in 1948 in Empédocle, under two possible titles: "Un récit?" and "Un récit", a fact that Jacques Derrida comments on several times in his book about Blanchot, Parages (130-36, 245-46, 275-77), even going so far as to reproduce the cover, contents page and first page of the Empédocle publication of "La Folie du jour" on pages 132-34. These earlier titles could be translated as "A story?" and "A story", giving Blanchot's and Davis's texts almost the same title. Even if Davis 
were unaware of this fact, it suggests a similar narratological focus to the texts.

La Folie du jour also appears to be ideal for reading Davis's response to Blanchot, not only for its questioning of narrative, but it is, as Manola Antonioli remarks, "peut-être le récit le plus énigmatique de Blanchot" [perhaps the most enigmatic of Blanchot's récits] ${ }^{1}$ (32). Indeed, Deborah Hess notes that "[Blanchot's] narrative works are progressively shorter and more abstract" (180), suggesting that "The Madness of the Day" might be viewed as a distillation of Blanchot's aesthetic. Both texts problematize the possibility of ever deciding on a single interpretation of events, or even in Blanchot's case, of being able to narrate a tale that satisfies that demand. Such indeterminacy is theorized by Blanchot, and I begin my analysis with a short consideration of his theory of the récit and how it may have influenced Davis. The rest of the article questions how Davis's story can be read as a response to Blanchot's. The indeterminacy in his fiction, I argue, attracted Davis to Blanchot as a writer, although she writes with much more focus on the interpersonal, emotional elements of narrative than Blanchot does, as he focuses in "The Madness of the Day" on the institutional use of narrative.

Both Davis and Blanchot question the possibility of narrative within their narratives. Blanchot's récits are difficult to read as they evade normal characteristics of narrative: none really concludes, none has a traditional three part story arc with beginning, middle and end. Davis herself has written of how difficult it was for her to produce an adequate summary of The One Who Was Standing Apart From Me (Proust 32-33). The texts require a different, deeper type of reading than other works, as Brian Fitch notes: "toute approche superficielle est vouée à l'échec: elle ne saurait déboucher que sur un constat d'incompréhension" [any superficial approach is bound to fail: it can only result in a statement of incomprehension] (7). Hess calls these texts "non-Aristotelian" (1) as they appear to eschew Aristotle's three poetic unities of place, time, and action. This means that the reader struggles with the texts, as their "literary competence" (Culler 131-52) is likely to be based in Aristotle's unities, which form the backbone of Western poetics.

Blanchot himself suggests a way out of Aristotelian narrative poetics in his theory of the récit, which he compares to the singing of the Sirens (Livre 9-17). It is: "un mouvement vers un point, non seulement inconnu, ignoré, étranger, mais tel qu'il ne semble avoir, par avance et par dehors de ce mouvement, aucune réalité" [a movement towards a point which is not only unknown, unheard of, strange, but such that it seems that it is not real before or outside of this movement] (Livre 13). The récit thus creates itself, at the same time pushing towards a place that is, like the Sirens' song, outside of the reach of conventional conceptions of reality. The récit is not the narration of the event (Livre 13); the narration is the event. Rather than producing a narrative that has a unity of time, place and action, the récit can enter into another time, "qui est le passage du chant réel au chant imaginaire" [which is the passage from the real song to the imaginary song] (Livre 15). It is this irregular and unreal relationship to time that defines the recit: it is narration which produces its own time, as well as its own event. Blanchot also notes that it avoids the trappings of fictionality (Livre 13) - it does not develop in the conventional way, but within its own framework. It is a text which is not assimilable to generic conventions other than its own. The récit is therefore a text where the narration is more significant than the narrative; reading the text is more about the experience of reading than being able to ascribe a causal sequence of the events described.

${ }^{1}$ All unacknowledged translations in this article are the author's own. 
This theory of the récit appears to have been attractive to Davis. Her stories also represent a departure from the accepted understandings of what a story might be, avoiding or complicating ideas of plot, character, and setting. For example, her novel The End of the Story interrupts its own narration to discuss and question the plausibility of that narration, disrupting the functioning of the plot. Some of Davis's stories are very reductive in what they include - in several instances, they are only one line long. In such stories, there cannot be more than just a name or a pronoun for a character. For example, in "Suddenly Afraid" (Varieties 189), all the character information given is the gender pronoun, "because she couldn't write the name of what she was." The reader is forced to supply the rest of the information, which means that each reader will envisage this female character differently. Stories like "A Mown Lawn" (Almost 2) tell no story, but present a text which reads more like a poem with development caused by association of ideas rather than narrative. It is its own event rather than the narration of any event. Blanchot and Davis share an affinity as their texts disrupt narrative conventions, especially that of closure. However, reading the texts shows how the link between them is more complex, with Davis responding in her own text to Blanchot's.

"The Madness of the Day" can be split into two movements. The first is a first person account of a man's life. He says he has lived in different circumstances: "J'ai été pauvre, puis plus riche, puis plus pauvre que beaucoup" (Folie 9) ["I have been poor, then richer, then poorer than many people" (Station Hill 191)]. ${ }^{2}$ There are various events that are recounted in this half of the narrative, such as the narrator being placed before a firing squad (Folie 11; Station Hill 191), being buried in mud in some sort of medical treatment (Folie 12; Station Hill 192), having his hand stabbed (Folie 14; Station Hill 193), falling into poverty and spending time in a "bas-fond surchauffé" [overheated basement] of a library (Folie 15; Station Hill 193), and seeing a man in a doorway giving way to a baby carriage (Folie 16; Station Hill 194). None of these incidents seems to lead to the next, and there are moments of reflection between them. Antonioli notes how "[l]e 'récit' pourrait sembler ... recommencer à chaque nouveau paragraphe" [the "récit" could seem ... to start again with each new paragraph] (33), and indeed, there is a feeling that the text is discontinuous, but at the same time the text does seem to present some sort of narrative development, with events noted as coming "après" (Blanchot, Folie 11) [“afterward” in Davis's translation (Station Hill 191)]. The construction of the text, with reflective passages between narrative passages suggests that the narrator is looking back over their life and trying to establish some sort of positioning for the later events. The beginning does not, however, explain the rest of the text.

The second movement of the text begins with the narrator recounting that "[i]e faillis perdre la vue, quelqu'un ayant écrasé du verre sur mes yeux" (Folie 18) ["I nearly lost my sight, because someone crushed glass into my eyes" (Station Hill 194)]. Yet this information, which becomes central to the development of the rest of the narrative, is not foregrounded by being placed at the beginning of a paragraph, but rather appears two sentences in. The casualness of the placement of what is effectively the pivotal moment of "The Madness of the Day" means that the reader almost misses its significance. It is as if the narrator wants to reduce the importance of the event. However, the rest of the text recounts a narrative that unfolds as a consequence of

\footnotetext{
2 All references to Davis's translation of La Folie du jour are to the most recent version, found in The Station Hill Blanchot Reader, unless otherwise noted. There are some differences between the two versions and it is assumed that the later version should be taken as the definitive translation.
} 
the damage to his eyes; the narrator is hospitalized and treated for the injuries and is questioned about how he could have come to have glass ground into his eyes. He is given a job in the institute, but the doctors and nurses find his acceptance of his circumstances unacceptable. It seems he should want to "rendre justice" (Folie 24) ["see justice done" (Station Hill 197)], and he sees the silhouette of the law, a feminine figure (just as "la loi" in French is a feminine noun), who speaks to him directly. He is locked up in what appears to be a mental hospital, as the doctor thinks he is "bien fou" (Folie 25) ["truly crazy" (Station Hill 198)]. The doctors continue to ask questions of him, which he says come back to the question of who threw glass into his face. He finds it difficult to tell his examiners the story they want to hear. It seems that the narrative he tells them may be the narrative the reader is reading, as it begins: "Je suis ni savant ni ignorant. J'ai connu des joies." (Folie 29) ["I am not learned; I am not ignorant. I have known joys" (Station Hill 199)], which is the same as the first line of La Folie du jour/"The Madness of the Day". The narrator concludes "Un récit. Non, pas de récit, plus jamais" (Folie 30) [“A story? No. No stories, never again” (Station Hill 199)].

Any summary of "The Madness of the Day" reduces the complexity of the narrative, giving a coherence that the text itself does not have. While the "story" of the text seems to centre on the narrative of the man who has had glass ground into his eyes, the refusal of the narrator to prioritize that event means that the centre of the story is shifted or dispersed. At the same time, as Leslie Hill (99) notes, it is only after that event that the text begins to follow any continuous narrative, effectively making it the centre of the story. Thus the glass attack seems to be both central and not central at the same time. It is tempting to try to resolve this duality, yet the text does not allow it.

Indeed, the text further complicates matters, as the narrator, just before recounting that someone crushed glass in his eyes, remarks that "Je n'avais pas d'ennemis. Je n'étais gêné de personne" (Folie 17) ["I had no enemies. No one bothered me" (Station Hill 194)]. This causes the reader to find it difficult to know how to value the statement that someone crushed glass into his eyes, which appears in the same paragraph. Hess sees the glass grinding as "a symbolic episode" (52), arguing that this would deprive the narrator of sight permanently. Hess's argument highlights the fictional nature of the text: in fiction apparently unrealistic moments need not perturb the reader's suspension of disbelief and may be accepted precisely because they appear in a fictional text. Blanchot's narrative works are not exempt from such moments, for example, J's miraculous reprieve from death in Death Sentence (L'Ârret 36; Death Sentence 20). The narrator of "The Madness of the Day" may be able to recover his sight in the story, precisely because it is a story, although even then he does not fully recover - "[m]ême guéri, je doutais l'être" (Folie 19) ["Even after I recovered, I doubted I was well" (Station Hill 195)] - suggesting that Hess's reading of the incident as symbolic reduces its effects within the narrative. The event both foregrounds the fictionality of the narrative and produces realistic consequences; a paradox that would seem not to be extraordinary in Blanchot's work.

The difficulty for the reader lies in the disjunction between someone who says that he had no enemies and that no one bothered him and then, almost immediately, says someone ground glass into his eyes. This is a violent act and it should not happen for no reason, suggesting that the narrator did have enemies. There is also, paradoxically, no reason why it could not be an act of random violence. The apparently motiveless nature of the crime is disturbing. It is not only the reader who has difficulty in accepting the narrator's account of the incident: the doctors keep 
asking him as well, and when he does tell them they dismiss his account, calling it nothing more than "ce commencement" [this beginning] (Folie 29), and exhort him to "en [venir] aux faits" (Folie 29) ["get down to the facts" (Station Hill 199)]. This might be taken as proof of the narrator's unreliability, as when other characters do not accept the narrator's word it becomes hard for the reader to do so, but in "The Madness of the Day" the doctors' questioning seems rather to originate in a position where it is impossible to accept that there may have been no motive, or no "story".

In French the word used for "story" in the last three paragraphs of the text is "récit" (Folie 29-30), causing Derrida (251-87) to question the narrative's generic status. For Derrida the text problematizes the genre of the récit, as it does not recount a story, but rather questions the possibility of telling a story (268). He even suggests that the " $\mathrm{I}$ " of the text may not necessarily refer to the same character throughout (269), although there is little evidence either way of this in the text itself. Derrida's reading of La Folie du jour/"The Madness of the Day" as a text about genres and the problem of the limit that the concept of genre includes is echoed by later commentators: Hill (98) brings up the question of the limit while Antonioli remarks that the text is about "l'impossibilité du récit" [the impossibility of narrative] (32).

Derrida points out that one of the ways that "The Madness of the Day" disorientates a traditional sense of story is through the moment where the text seems to fold back on itself and quote the beginning: "ce bord supérieur ou initial, ce qu'on appelle la première ligne du livre, vient faire une poche à l'intérieur du corpus" [this superior or initial edge, what is called the first line of the book, comes to make a pocket inside the work] (271). This repetition of the beginning threatens to repeat the whole text, although it continues for only three sentences before the narrator returns to the point in the narrative where he is being questioned: "Un récit? Je commençai: Je ne suis ni savant ni ignorant. J'ai connu des joies. C'est trop peu dire. Je leur racontai l'histoire tout entière" (Blanchot, Folie 29) [“A story? I began: I am not learned; I am not ignorant. I have known joys. That is saying too little. I told them the whole story" (Station Hill 199)]. Davis's first translation from 1977 places the repeated beginning of the text in quotation marks: "A story? I began: 'I am neither learned nor ignorant. I have known joys. That is saying too little.' I told them the whole story" ("Madness" 176). The quotation marks contain the repetition, clarifying its status as a citation, which neutralizes the destabilizing effects that Derrida (270-73) attributes to it. It is perhaps to restore the ambiguity of whether or not the repetition is a citation that Davis removed the quotation marks in the revised translation.

Derrida's comments focus on the narratological elements of the text, but it is not enough to focus solely on these: the disturbance of narrative that takes place in the text is in keeping with the diegetic situation of the narrator trying to respond to the question of who threw glass into his face (Folie 28; Station Hill 198). For instance, Derrida sees a second fold, or "invagination" as he prefers to call it (272), in the repetition of "Un récit?" /"A story?," which comes before the narrator starts telling his story to the examiners and then again after, in the text's last line. Derrida views this as excluding possibly the last line of the text from the récit, situating it as an appendage. This speculation is not warranted, as the concluding line of the text follows from the narrator's protests that he cannot tell a story: “je n'étais pas capable de former un récit de ces événéments" (Folie 29) ["I was not capable of forming a story out of these events" (Station Hill 199)]. In one way this inability to tell a story is also a continuation of his withdrawal, which becomes clear when he remarks: "Cependant quelque chose en moi cessait assez vite de vouloir" 
(Folie 21) ["Yet something inside me quickly stopped wanting" (Station Hill 196)]. He stops wanting in general, and it seems that this withdrawal is at least partially responsible for his being locked up; he no longer follows conventions and thus seems mad within the order of reason represented by the medical profession. His inability to tell a story is met by incredulity, although the incredulity is accredited to what may be a hallucination of the narrator (and therefore an externalisation of his own incredulity):

Mais, étant deux, à cause de cela ils étaient trois, et ce troisième restait fermement convaincu, j'en suis sûr, qu'un écrivain, un homme qui parle et qui raisonne avec distinction, est toujours capable de raconter des faits dont il se souvient. (Folie 29-30)

But because there were two of them, there were three, and this third remained firmly convinced, I am sure, that a writer, a man who speaks and reasons with distinction is always capable of recounting facts that he remembers. (Station Hill 199)]

While the text plays with the impossibility of telling a story and to some extent does not tell a story, it also tells a story. This appears contradictory, but the logic of the text is one of contradiction. The text does not provide a uniform narrative where all parts fit with Aristotle's unities of time, place and action; in this sense it does not tell a story. Yet at the same time, the text presents a narrative, albeit one with gaps and uncertainties: the narrative of a man who chooses not to sue someone who ground glass into his eyes, a man who cannot tell the story of how that happened. Moreover the man can only provide a non-Aristotelian narrative, which is unacceptable to the medical and juridical questioners, who require motive, narrative causality, and a unity of time, place and action. The reader is placed in the same position as these examiners, trying to tie up the loose ends. Yet the reader can accept the non-logic of the narration, unlike the examiners who are trapped in their institutional setting which requires a certain form of logic. The reader does not have to rationalize the story; they can accept it with its contradictions.

Lydia Davis's "Story" presents a perspective that almost mirrors that of "The Madness of the Day." Instead of the narrator producing a contradictory narrative that is unacceptable in the institutional setting where it is told, the narrator is told a story by her lover and cannot decide whether or not it is true. The narrator in "Story" is therefore in the position of the examiners in La Folie du jour, but she is not so bounded by institutional logic. In "Story" the reader is made to identify with the narrator's position and follow her interpretation of events with the hope of arriving at a conclusion. Davis therefore shifts the perspective away from a narrator trying and failing to tell a story, as in Blanchot's récit, to the narrator being told a story she cannot accept. The perspective is reversed, suggesting that Davis's story is performing some sort of response to the text she had previously translated.

"Story" is a story of two parts: the first (Break it down 3-6) is narrated in the present tense by a female narrator and describes an evening when her lover, whom she does not live with, has stood her up to see his old girlfriend, the argument over the phone which ensues and the narrator's visit to her lover's house and the confusing discussion there. The narrator finds the explanation given by her lover unsatisfactory and thinks that "[e]verything he says is a contradiction" (4). A second part (6-7) entails the narrator trying to "figure it out." This section involves her recounting to herself (and the reader) the tale her lover has told her and questioning it: 
So they went to the movies and then came back to his place and then I called and then she left and he called back and then I called back twice but he had gone out to get a beer (he says) and then I drove over and in the meantime he had returned from buying beer and she had also come back and she was in his room so we talked by the garage doors. But what is the truth? (6)

She continues to question his story, unsure of whether or not he has told the truth. She knows he does not always tell the truth (7), and this makes her unsure of him at other times. In the end she is unsure of whether the truth matters, although it would allow her to "come to some conclusions" (7) about some questions she has of the relationship:

whether he is angry at me or not; if he is, then how angry; whether he still loves her or not; if he does, then how much; whether he loves me or not; how much; how capable he is of deceiving me in the act and after the act in the telling. (7)

It seems impossible that she should be able to answer these questions just from knowing the truth about that one evening; even knowing where her lover had been, it would be difficult to tell if he was angry, or how much he loved either the narrator or his old girlfriend.

The two part structure of "Story" is reminiscent of the two part structures of Blanchot's récits, Death Sentence and The Last Man; however, the relationship between the two parts of Davis's story is a lot clearer than the relationship between the two parts of Death Sentence as the latter one is clearly set up as a thinking through of the earlier part. The combination of reflection and narration also echoes "The Madness of the Day," although there they are mixed throughout the text. The reflective passages in "Story" serve to help the narrator to try to understand the encounter, whereas in "The Madness of the Day" they seem rather to disperse any decidable meaning or narrative: the reflections on books (Folie 15; Station Hill 193), for example, seem unrelated to the rest of the text. However, Perloff notes that incomprehension is also the function of the second part of "Story": "the narrator's re-recounting of what she has already told us ... gradually blocks all possibility of interpreting the signs" (207). By questioning all the parts of the preceding narrative, and the permutations of their possibilities, the narrator arrives at a position where the multiple possibilities cannot be reconciled or the most likely chosen. As Perloff describes it, "[t]he 'story' cannot reach closure" (208). She also notes that the narrator appears to lose interest in the events of the narrative, "for it is the puzzle itself which has become the narrator's obsession" (208). This also appears to be Karen Alexander's view of "Story": "[t]he events she relates prior to her concluding calculations serve only to make those calculations possible" (170).

Yet those calculations are not "possible" per se, as the narrator cannot arrive at any answer. The narrator's "obsession" may not be the puzzle either, but rather the concluding line of the story: "how capable he is of deceiving me in the act and after the act in the telling" (Davis, Break it down 7). The threat of betrayal motivates the narrator's attempts to understand, rather than an intellectual interest in the possibility of truth. The beginning of "Story" suggests her anxiety over her lover:

I get home from work and there is a message from him: that he is not coming, that he is busy. He will call again. I wait to hear from him, then at nine o'clock I go to where he lives, find his car, but he's not home. I knock at his apartment door and then at all the garage doors, not knowing which is his - no 
answer. I write a note, read it over, write a new note, and stick it in his door. (3)

This opening sets up the idea that something has been planned, and the narrator is upset by her lover's cancellation of the date. She goes over to look for him at $9 \mathrm{pm}$. She leaves a note, which she is careful enough to redraft, but only after exhausting the possibilities for finding him at home. The narrator seems to be thorough, almost to a point of obsession, and her knocking on every garage door in attempts to find her lover can be related to her later attempts to decipher the truth: she is capable of entertaining several possibilities, but only in the hope that one of them might be true.

The narrator's suspicions of her lover are revealed later on, when they are talking: "I am waiting for him to say that she is there also that it's all over between us" (5), and when he does not she notes "I have the feeling he did intend to say something like that" (5). Here the possibility for what he can say or might say encroaches on what he does say. The narrator is not able to accept what she is told: unlike the questioners in La Folie du jour, who are bound by an institutional need for motive, her jealousy causes her to be cautious and mistrustful. At the same time she knows he is withholding information from her, as they are standing outside and not in his room, as one might expect. He admits that his old girlfriend is there, but assures the narrator that she was not when they spoke on the phone. His acts and his statements seem difficult to reconcile and it would appear that the narrator's suspicion is justified. She is haunted by what she cannot know, which relates to what her lover and his old girlfriend have been up to, whether or not he has been unfaithful, etc. As Perloff asks, “is 'old' equivalent to 'former'?" (207). The lover's relationship with his old girlfriend is never clear.

"Story" then, is about jealousy: the question is not about finding out some truth, but rather, more specifically, if the lover has deceived her, and how. The attempt to "figure it out" at the end of the story is an attempt to overcome this jealousy, yet it perversely has the opposite effect of making it impossible to find the truth and so allay the jealous fantasies. Sigmund Freud (163) notes that a child may repeat unpleasurable experiences in an attempt to master them: it seems that the narrator here is trying to master the narrative through repeating it, yet she cannot because she does not know, and so repeats with different possibilities. The effect is not mastery but rather a dissipation of control: she cannot know what happened and cannot control it or her lover. This is reminiscent of Marcel's struggles with Albertine in Proust's $\grave{A}$ la recherche du temps perdu (which Davis also translated the first volume of); the unknown, in the spectre of Albertine's possible lesbianism, haunts him.

The relationship between the lovers needs trust for it to work, and suspicion means that not only is the lover's word put into question, but also the relationship: she expects him to say it is over (Break it down, 5), she questions if he loves her and how much (7). As Josh Cohen notes, in relation to "Story": "[t]he everyday interaction of lovers is built on the shaky foundations of one or other 'story' whose correlation with 'the truth' can be neither confirmed nor refuted" ("Aesthetic Theory" 77). All loving relationships rely on accepting a narrative: by not accepting that narrative the conditions of the relationship are questioned.

The narrator in "Story," like the doctors in "The Madness of the Day," thinks that it should be possible to arrive at a story, but she cannot. There is a hint she may stop trying to make sense of it, as she notes "[m]aybe the truth does not matter" (Break it down 7). The narrator of "The Madness of the Day," on the other hand, begins to repeat only to stop the repetition after a few 
words (Folie 29; Station Hill 199). He seems not to want to control the events or to revisit them. The difference lies in the relationships the narrators have with other people: the narrator of "The Madness of the Day" is alone, whereas the narrator of "Story" is involved in an amorous relationship. For her, interpreting the story is connected to her acceptance of her lover, whereas Blanchot's narrator is being asked to find a story to fulfil the abstract notion of justice, rather than an emotional goal. The motivation for the story is therefore very different. One is unavoidably facing a failure to reach a conclusion; the other cannot entertain the basis on which any conclusion could be based. Blanchot's narrator is not interested in or not capable of clearing up any ambiguities, whereas Davis's narrator would like to, but cannot. The effect in both narratives is, however, a failure to find any closure and a questioning of narrative's possibility to provide a complete "story."

The narratological similarities between the two texts show evidence of an affinity of approach in Davis's and Blanchot's work. However, there are also important differences in motivation of the narrators of the texts, suggesting that Davis moves away from the terrain covered by Blanchot in her own writing. She creates characters and situations that are much more down to earth than Blanchot's - "Story," for instance, focuses on a woman not trusting her boyfriend, rather than the elaborate mental deterioration of the narrator in La Folie du jour. She writes in "Story" in a way that is more immediately based in emotional reactions, compared to the emotional blankness of Blanchot's narrator in La Folie du jour. Blanchot's influence on Davis, then, cannot be considered in simple terms of similarities appearing in their works or the influence his theories have had on her. Rather, Davis stages the same narrative impasse in "Story" that Blanchot explores in "The Madness of the Day," but twists and reconfigures it. Davis's story can therefore be read as a form of response to Blanchot's because it investigates the emotional territory that the narrator in Blanchot's fiction will not or cannot.

If Davis's story can be read as her fictional response to a text that she translated, it is also possible to say that her translation of "The Madness of the Day" offered her another way of responding to that text by rewriting it in English. In fact, the translation is one level of response and her story is another. She has mentioned that she translates because she enjoys "assuming a disguise" (McCaffery 75), but her translation of Blanchot does not appear to be solely a disguise: by translating La Folie du jour, she worked through a text that questioned narrative in a way that she herself was interested in. Her attraction to Blanchot's writing, as I noted earlier, stems from this shared questioning of narrative and the affinity she felt for that writing. Susan Bassnett remarks that "frequently writers translate other people's works because those are the works they would have written themselves had they not already been created by someone else" (175) and the similarity in the questioning of the possibility of a "story" in Blanchot's and Davis's text seems to bear this out, especially as Davis translates La Folie du jour in a way that shows a respect for the French source text. However, it is equally important to recognize that Davis's story focuses more on the personal aspects of narrative than Blanchot's: her concern is for the emotional response that stories evoke, while Blanchot focuses more on the institutional need for narrative as a form of understanding. The difference between them allows Davis's work to be read as a response to Blanchot's; in her story she asserts her own authorial persona in a way that she does not in the translation.

The divide between her identities as a translator and as an author, then, is blurred by Davis's response to Blanchot. Davis can be seen to be exploring in her own story an element that is 
already present in a text she has translated. However, in her translation she is exploring a narrative technique that is also present in her stories. There is a continuity between her practice as an author and her practice as a translator. Davis, like other author-translators, questions the separation between translation and writing. However, in Davis's case, the two activities do remain separate despite being interlinked, as her story is a response to a translation and the two texts remain clearly defined paratextually as a story by Davis and a translation by Davis. Only in a loosely metaphorical sense could "Story" be considered a translation of "The Madness of the Day" because Davis's story does not repeat the same narrative as Blanchot's text, but rather creates another text that both answers and questions the narrative of the earlier text. Davis's identity as an author is inflected by her identity as a translator of Blanchot, the trace of which can be found in her response to his work in her own. 


\section{REFERENCES}

Alexander, Karen. "Breaking It Down: Analysis in the Stories of Lydia Davis." Scribbling Women \& the Short Story Form: Approaches by American \& British Women Writers. Ed. Ellen Burton Harrington. New York: Peter Lang, 2008. 165-77

Antonioli, Manola. L'écriture de Maurice Blanchot: Fiction et théorie. Paris: Éditions Kimé, 1999.

Bassnett, Susan. "Writing and Translating." The Translator as Writer. Eds. Susan Bassnett and Peter Bush. London: Continuum, 2006. 173-83.

Bernofsky, Susan. Foreign Words: Translator-Authors in the Age of Goethe. Detroit: Wayne State UP, 2005.

Blanchot, Maurice. Au moment voulu. Paris: Gallimard, 1951.

—. Celui qui m'accompagnait pas. Paris: Gallimard, 1953.

—. "Death-Halt." Trans. Lydia Davis. Living Hand 4 (1975): 3-28.

—. "Death Sentence." Trans. Lydia Davis. Georgia Review 30.2 (1976): 379-403.

—. Death Sentence. 1978. Trans. Lydia Davis. Barrytown: Station Hill Press, 1998.

- La Folie du jour. 1973. Paris: Gallimard, 2002.

—. L'Arrêt de mort. 1948. Paris: Gallimard, 1977.

—. Le Dernier homme. Paris: Gallimard, 1957.

- Le Livre à venir. Paris: Gallimard, 1959.

- The Gaze of Orpheus, and Other Literary Essays. Ed. P. Adams Sitney. Trans. Lydia Davis. Barrytown: Station Hill Press, 1981.

—. The Last Man. Trans. Lydia Davis. New York: Columbia UP, 1987.

—. "The Madness of the Day." Trans. Lydia Davis. Tri-Quarterly 40 (1977): 168-77.

—. The Madness of the Day. Trans. Lydia Davis. Barrytown: Station Hill Press, 1981.

- The One Who Was Standing Apart From Me. Trans. Lydia Davis. Barrytown: Station Hill Press, 1993.

- The Sirens' Song. Ed. Gabriel Josipovici. Trans. Sacha Rabinovitch. Brighton: Harvester, 1982.

- The Space of Literature. Trans. Ann Smock. Lincoln: U of Nebraska P, 1982.

- The Station Hill Blanchot Reader. Ed. George Quasha. Trans. Lydia Davis, Paul Auster and Robert Lamberton. Barrytown: Station Hill Press, 1999.

-When the Time Comes. Trans. Lydia Davis. Barrytown: Station Hill Press, 1985.

Cohen, Josh. "Aesthetic Theory, Psychoanalysis and the Ironic End of Art." Parallax 11.4 (2005): 71-80.

—_."Reflexive incomprehension: on Lydia Davis.” Textual Practice 24.3 (2010): 501-16.

Culler, Jonathan. Structuralist Poetics: Structuralism, Linguistics and the Study of Literature. 1975. London: Routledge Classics, 2002.

Davis, Lydia. Almost no memory. New York: Farrar Strauss Giroux, 1997.

—. Break it down. 1986. New York: Serpent's Tail, 1996.

- Proust, Blanchot and a Woman in Red. Paris: Centre for Writers \& Translators, AUP; Lewes: Sylph Editions, 2007.

—. Story and Other Stories. Great Barrington: The Figures, 1983.

—. The End of the Story. 1995. New York: Picador, 2004.

—. The Thirteenth Woman and Other Stories. New York: Living Hand, 1976. 
Varieties of Disturbance. New York: Farrar Strauss Giroux, 2007.

Derrida, Jacques. Parages. Paris: Galilée, 1986.

Fitch, Brian T. Lire les récits de Maurice Blanchot. Amsterdam: Rodolpi, 1992.

Flaubert, Gustave. Madame Bovary: Provincial Ways. Trans. Lydia Davis. London: Penguin, 2010.

Freud, Sigmund. "Beyond the Pleasure Principle." Trans. John Reddick. The Penguin Freud Reader. Ed. Adam Philips. London: Penguin, 2006. 132-95.

Friedländer, Saul, and Mahmoud Hussein. Arabs and Israelis: A Dialogue. Trans. Paul Auster and Lydia Davis. London: Holmes and Meier, 1975.

Gill, Carolyn Bailey, ed. Maurice Blanchot: The Demand of Writing. London: Routledge, 1996.

Haase, Ulrich, and William Large. Maurice Blanchot. London: Routledge, 2001.

Haviland, Beverly. "Missed Connections." Partisan Review 56.1 (1989): 151-57.

Hess, Deborah M. Complexity in Maurice Blanchot's Fiction: Relations Between Science and Literature. New York: Peter Lang, 1999.

Hill, Leslie. Blanchot: Extreme Contemporary. London: Routledge, 1997.

Leiris, Michel. Brisées: Broken Branches. Trans. Lydia Davis. San Francisco: North Point Press, 1989.

McCaffery, Larry. "Deliberately, Terribly Neutral: An Interview with Lydia Davis." Some Other Frequency: Interviews with Innovative American Authors. Ed. Larry McCaffery. Philadelphia: U of Pennsylvania P, 1996. 59-79.

Perloff, Marjorie. "Fiction as Language Game: The Hermeneutic Parables of Lydia Davis and Maxine Chernoff." Breaking the Sequence: Women's Experimental Fiction. Ed. Ellen G. Friedman and Miriam Fuchs. Princeton: Princeton UP, 1989. 199-214.

Proust, Marcel. À la recherche du temps perdu. Ed. Pierre Clarac and André Ferré. 3 vols, Paris: Gallimard Bibliothèque de la Pléiade, 1954.

—. The Way by Swann's. Trans. Lydia Davis. London: Allen Lane, 2002.

Wood, James. "Songs of Myself: Lydia Davis's Very, Very Short Stories." New Yorker 19 Oct. 2009: 88-91.

Ziolkowski, Thad. [Interview with Lydia Davis]. Index Magazine (1997): http://www.indexmagazine.com/interviews/lydia davis.shtml. 